\title{
The impact of the collision training use of the arms on some special physical variables and the skillful performance of boxing beginners
}

\section{"Dr/ Mohamed Zakaria Baldam}

Introduction and research collision training. The

\section{problem}

Sports training is one of the best methods of developing the level of player, which in turn makes the players able to reach the highest levels of sports through the development of the individual's physical, psychological, skill and planning.

In addition, Hameed Rafaki (2003) agrees that the integrated physical preparation is the basis on which the boxer will be built on the basis of skill and planning. Without this foundation, the high levels cannot be reached, and the movements of the boxer should be developed quickly and quickly. In the counter-attack, the boxer must be strong and graceful and have a great deal of endurance (14: 2) (52:5)

As the science of training progresses, a number of modern training methods have emerged in the field of sports training. These include
American Society of Sports Medicine points out that collision training is a safe and useful exercise as well as an activity that improves the dynamic ability of its practitioners.

The concept of collision training is attributed to an expert from the former Soviet Union, Verkhanski, who launched this kind of training with Collision Training, also known as Reactive Strength Exercises, derived from the nature of plaumetric exercises. Donald Shaw (2008) notes that collision training is characterized by high intensity by directly affecting the musculoskeletal system and connective tissue $(18: 3,4)$

Collision training is a set of exercises designed to develop muscle elasticity through the so-called elongation and shortening cycle.

It is a special method for developing explosive ability and depends on the moments of

"Lecturer, Department of Combat Sports- Faculty of Physical Education - Tanta University

Assiut Journal For Sport Science Arts 
wrestling and braking that occur as a result of the weight of the body in its dynamic movement such as jump back. The development of muscular capacity thus improves the dynamic performance of movements (24: 380)

Gambetta (2001) points out that collision training is a concentrated muscle activity to improve the level of strength based on a physiological fact that the muscle can exert greater force or effort if prolonged before movement. Gambetta (2009) points out that collision training works to stimulate strength in training movements by exploiting the locomotors activity resulting from a weight loss in reversing muscle work.

And that the exercises that depend on the energy of rubber and the work of sensory receptors reflect the most useful to reduce the time between prolongation and shortening and the energy stored in the muscles due to lengthening at rapid rates during the phase of contraction and participate in the first moments of the second (10: 42,43)

Adel Sabri (2009), Abu El-Ola Abd El-Fattah (2002)
(3) must match the special training in building and strength on the movements of competition and that strength exercises should focus on the movements of contractions prevailing competition exercises in order to achieve the harmony of the requirements of performance. : 9) $(14: 1)$

Sharkey (2000) states that the secrets to the success of this training are due to physiological fact that the muscle gives greater strength if it can be flexed before it is contracted directly, which improves the mechanism of reflection and increases relaxation and stores a large energy that increases the efficiency and speed of constriction 24: 82.)

Through the experience of the researcher in the academic field and the field of training in boxing training, he found that the exercises used to develop muscular ability in boxing exercises are traditional and non-interesting, which affects the boxers that have a negative impact and does not achieve the training objective.

This led the researcher to carry out this study to identify the effect of using 
training Armchair collisions on some special physical variables and skillful performance of boxing beginners

\section{Research goal}

The aim of this study is to identify the impact of the use of collision training on the arms on some special physical variables and the skillful performance of boxing beginners

\section{Research hypotheses}

- $\quad$ There are statistically significant differences between the average of the pre and post measurements in the level of some special physical variables and the skillful performance of boxing beginners.

- There are statistically significant differences between the average of the pre and post measurements in the level of some special physical variables and the skillful performance of the early boxing control group.

There are statistically significant differences between the average of the post criteria in the experimental and control research groups, some special physical variables and skill performance and for the benefit of boxing beginners.

\section{Research Methodology-:}

The researcher used the experimental method to suit the nature of the research, with a pilot design of two groups, one of which is experimental. The proposed training program is applied using collision training and the other is a control and the traditional program is applied.

\section{Society and Sample Search- :}

The original community of the sample included 28 boxes of boxing beginners in the age group (15-17) years who were selected by the deliberate method of the Mahalla Spinning Club and the Tanta Athletic Club of the Western Region of Amateur Boxing. They were divided into two groups, one experimental (10) boxers and the other an officer. Boxers and (8) boxers for exploratory studies. 
Table (1)

The homogeneity of the research sample in growth rates, physical variables and skill level $(\mathrm{N}=28)$

\begin{tabular}{|c|c|c|c|c|c|}
\hline Variables & $\begin{array}{c}\text { Measure } \\
\text { unit }\end{array}$ & Average & SMA & $\begin{array}{l}\text { standard } \\
\text { deviation }\end{array}$ & $\begin{array}{c}\text { Torsion } \\
\text { coefficient }\end{array}$ \\
\hline Year & Year & 16.25 & 16.00 & 0.90 & 0.8333 \\
\hline Height & $\mathrm{Cm}$ & 165.28 & 165.00 & 3.11 & 0.2700 \\
\hline Weight & $\mathrm{Kg}$ & 56.25 & 56.00 & 3.33 & 0.225 \\
\hline The training age & Year & 2.85 & 2.80 & 0.60 & 0.249 \\
\hline $\begin{array}{l}\text { Push a medical ball } \\
\text { with your right hand }\end{array}$ & M & 6.20 & 6.00 & 0.27 & 2.22 \\
\hline $\begin{array}{l}\text { Push a medical ball } \\
\text { with the left hand }\end{array}$ & M & 5.58 & 5.50 & 0.36 & 0.666 \\
\hline $\begin{array}{l}\text { Punching the left } \\
\text { straight fist on } a \\
\text { punching bag for } 20 \\
\text { seconds }\end{array}$ & Punch & 30.15 & 30.00 & 0.52 & 0.865 \\
\hline 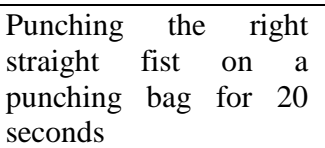 & Punch & 43.25 & 43.00 & 1.17 & 0.641 \\
\hline $\begin{array}{l}\text { Punching both hands } \\
\text { on a punching bag } \\
\text { with straight fists for } \\
20 \text { seconds }\end{array}$ & Punch & 41.25 & 41.00 & 1.33 & 0.563 \\
\hline $\begin{array}{l}\text { Punching for } 10 \\
\text { seconds on the wall pad }\end{array}$ & Punch & 20.36 & 20.00 & 1.52 & 0.710 \\
\hline $\begin{array}{l}\text { Imagining } \\
\text { punching For } 10 \\
\text { seconds }\end{array}$ & Punch & 21.69 & 21.50 & 1.17 & 0.487 \\
\hline $\begin{array}{l}\text { Tilt and bend the } \\
\text { arms for } 20 \text { seconds }\end{array}$ & No & 21.63 & 21.50 & 1.63 & 0.239 \\
\hline $\begin{array}{l}\text { Tilt sloping stand } \\
\text { for } 20 \text { seconds }\end{array}$ & No & 18.32 & 18.00 & 1.28 & 0.750 \\
\hline \multicolumn{3}{|c|}{$\begin{array}{l}\text { Table 1 shows the } \\
\text { mean, mean, standard deviation } \\
\text { and torsion coefficient of the } \\
\text { variables in question. It is clear } \\
\text { that the torsion coefficient is } \\
\text { between } \pm 3 \text {, which gives a } \\
\text { direct indication of the absence }\end{array}$} & \multicolumn{3}{|c|}{$\begin{array}{l}\text { of data from irregular } \\
\text { distribution defects. } \\
\text { Data collection methods- : } \\
\text { Devices and tools used: } \\
\text {-Resist meter for measurement } \\
\text { of length. - Medical balance for } \\
\text { measuring weight. - Wooden } \\
\text { boxes height } 25 \mathrm{~cm} \text {. }\end{array}$} \\
\hline
\end{tabular}


-Tape measure. - Training gloves. - Cushions for you.

-Bags for you. - Jump ropes. Stop Watch.

-Medical balls 3 kg.- robe rubber.

\section{Measurements and tests used} in the research- :

\section{Performance level tests- :}

-oblique sloping arms flexion for $20 \mathrm{w}$ to measure muscle capacity.

-sloping slant to stand and then sit squat and then stand for (1) minutes to measure the tolerance of force

-Test the strength of the right hand in the performance of the right straight punch.

-Test the strength of the left hand in the performance of the left straight punch.

-Measure the number of left straight punches in 20s.
-Measuring the number of right straight punches in $20 \mathrm{~s}$.

-Measuring the number of right and left straight punches in 20 s .Coaching Program:

The researcher developed the collision training program after a reference analysis of the Arab and foreign scientific references (7), (8), (14), (16) and (23) that used the collision training.

Distribution of daily unit time in the collision training program:

The researcher divided the time of the training unit into three sections. The content of the daily training module was distributed as well as the formation of the training load and the distribution of the training exercises on the daily and weekly training units during the preparation period as shown in Table (5)

Table (5)

Time distribution of the three sections of the daily training units of the collision training

\begin{tabular}{|c|c|c|c|c|}
\hline Serial & \multicolumn{2}{|c|}{ Parts of the daily module } & Content & Time \\
\hline \multirow[t]{2}{*}{1} & \multirow{2}{*}{ Preface } & \multirow{2}{*}{ Warming } & Management works & (5) $\mathrm{m}$ \\
\hline & & & Configure the body & $15 \mathrm{~m}$ \\
\hline 2 & Main & $\begin{array}{l}\text { Physical } \\
\text { preparation }\end{array}$ & $\begin{array}{l}\text { Perform the } \\
\text { collision training } \\
\text { within the search }\end{array}$ & $\begin{array}{l}\text { Time is determined } \\
\text { according to the } \\
\text { characteristics of the } \\
\text { application stage }(60-65) \mathrm{s}\end{array}$ \\
\hline \multirow[t]{2}{*}{3} & Final & Calming down & $\begin{array}{l}\text { Relaxation exercises } \\
\text { recreation }\end{array}$ & $5 \mathrm{~m}$ \\
\hline & Total time & & & $90 \mathrm{~m}$ \\
\hline
\end{tabular}


Program Planning: Daily and weekly training during the program preparation period

\begin{tabular}{|c|c|c|c|c|c|c|c|c|c|}
\hline \multirow[t]{2}{*}{$\begin{array}{l}\text { Week } \\
\text { No }\end{array}$} & \multirow[t]{2}{*}{ day } & \multirow[t]{2}{*}{ Activity } & \multicolumn{2}{|c|}{$\begin{array}{c}\text { intensity \% } \\
\text { Of } \\
\text { Endurance }\end{array}$} & \multirow[t]{2}{*}{$\begin{array}{c}\text { Week } \\
\text { No }\end{array}$} & \multirow[t]{2}{*}{ day } & \multirow[t]{2}{*}{ Activity } & \multicolumn{2}{|c|}{$\begin{array}{l}\begin{array}{c}\text { \%intensity } \\
\text { Of } \\
\text { Endurance }\end{array} \\
\end{array}$} \\
\hline & & & Day & Week & & & & Day & Week \\
\hline \multirow{3}{*}{ First } & Sunday & \multirow{14}{*}{$\begin{array}{l}\text { Collision } \\
\text { Exercises }\end{array}$} & $30 \%$ & \multirow[t]{3}{*}{$40 \%$} & \multirow{3}{*}{ Fifth } & Sunday & \multirow{14}{*}{$\begin{array}{l}\text { Collision } \\
\text { Exercises }\end{array}$} & $65 \%$ & \multirow[t]{3}{*}{$70 \%$} \\
\hline & Tuesday & & $40 \%$ & & & Tuesday & & $70 \%$ & \\
\hline & Thursday & & $50 \%$ & & & Thursday & & $75 \%$ & \\
\hline \multirow{3}{*}{ Second } & Sunday & & $45 \%$ & $50 \%$ & \multirow{3}{*}{ Sixth } & Sunday & & $65 \%$ & \multirow[t]{3}{*}{$70 \%$} \\
\hline & Tuesday & & $50 \%$ & & & Tuesday & & $70 \%$ & \\
\hline & Thursday & & $55 \%$ & & & Thursday & & $75 \%$ & \\
\hline \multirow{3}{*}{ Third } & Sunday & & $45 \%$ & $60 \%$ & & Sunday & & $75 \%$ & $80 \%$ \\
\hline & Tuesday & & $50 \%$ & & Seventh & Tuesday & & $80 \%$ & \\
\hline & Thursday & & $55 \%$ & & & Thursday & & $85 \%$ & \\
\hline \multirow{5}{*}{ Fourth } & Sunday & & $55 \%$ & $60 \%$ & \multirow{5}{*}{ Eightieth } & Sunday & & $80 \%$ & \multirow[t]{5}{*}{$80 \%$} \\
\hline & Tuesday & & $60 \%$ & & & Tuesday & & $80 \%$ & \\
\hline & Thursday & & $65 \%$ & & & Thursday & & $80 \%$ & \\
\hline & Tuesday & & $60 \%$ & & & Tuesday & & $80 \%$ & \\
\hline & Thursday & & $65 \%$ & & & Thursday & & $80 \%$ & \\
\hline
\end{tabular}

After studying the many references and research and previous studies in the field of training in general and the boxing in particular (1), (2), (6), (7), (9) Based on the pre measurement of the research sample, To the following:

-Total program time (8) eight weeks

-Number of training units during the week (3) three units.
-The total number of units (24) twenty-four training units.

The researcher divided the implementation period into three stages.

-The general preparation stage lasted (12) units.

-Special preparation stage and took (9) units.

-Pre-competitions and took (3) units.

View and discuss the results 
Table (2)

The significance of the differences and the rates of improvement between the averages of the pre and post measurements of the research sample Experimental tests in physical and skill variables for boxing $N=10$

\begin{tabular}{|c|c|c|c|c|c|c|c|c|c|}
\hline \multirow[t]{2}{*}{ Tests } & \multirow[t]{2}{*}{$\begin{array}{c}\text { Measure } \\
\text { unit }\end{array}$} & \multicolumn{2}{|c|}{$\begin{array}{c}\text { Pre } \\
\text { measure }\end{array}$} & \multicolumn{2}{|c|}{$\begin{array}{c}\text { Post } \\
\text { measure }\end{array}$} & \multirow{2}{*}{$\begin{array}{c}\text { Difference } \\
\text { between } \\
\text { the two } \\
\text { averages }\end{array}$} & \multirow[t]{2}{*}{$\begin{array}{c}\text { Improvement } \\
\text { rate }\end{array}$} & \multirow[t]{2}{*}{$\begin{array}{c}\text { Value (T) } \\
\text { Calculated }\end{array}$} & \multirow[t]{2}{*}{$\begin{array}{c}\text { Level of } \\
\text { significance }\end{array}$} \\
\hline & & $\mathrm{S}$ & $\pm \mathrm{E}$ & $\mathrm{S}$ & $\pm \mathrm{E}$ & & & & \\
\hline $\begin{array}{l}\text { Push a } \\
\text { medical } \\
\text { ball with } \\
\text { your right } \\
\text { hand }\end{array}$ & $\mathrm{Cm}$ & 6.18 & 0.52 & 9.10 & 0.39 & 2.92 & $32.08 \%$ & 6.68 & Indicated \\
\hline $\begin{array}{l}\text { Push a } \\
\text { medical } \\
\text { ball with } \\
\text { the left } \\
\text { hand }\end{array}$ & $\mathrm{Cm}$ & 5.55 & 0.32 & 8.65 & 0.52 & 3.10 & $35.83 \%$ & 6.32 & Indicated \\
\hline $\begin{array}{l}\text { Punching } \\
\text { the left } \\
\text { straight } \\
\text { fist on a } \\
\text { punching } \\
\text { bag for } 20 \\
\text { seconds }\end{array}$ & Punch & 30.10 & 0.87 & 36.25 & 0.21 & 6.15 & $16.96 \%$ & 5.52 & Indicated \\
\hline $\begin{array}{l}\text { Punching } \\
\text { the right } \\
\text { straight } \\
\text { fist on a } \\
\text { punching } \\
\text { bag for } 20 \\
\text { seconds }\end{array}$ & Punch & 43.20 & 0.36 & 49.36 & 0.17 & 6.16 & $12.47 \%$ & 5.63 & Indicated \\
\hline $\begin{array}{l}\text { Punching } \\
\text { both } \\
\text { hands on } \\
\text { a } \\
\text { punching } \\
\text { bag with } \\
\text { straight } \\
\text { fists for } \\
20 \\
\text { seconds }\end{array}$ & Punch & 41.11 & 0.21 & 46.21 & 0.33 & 5.10 & $11.03 \%$ & 5.47 & Indicated \\
\hline $\begin{array}{l}\text { Punching } \\
\text { for } 10 \\
\text { seconds } \\
\text { on the } \\
\text { wall pad }\end{array}$ & Punch & 20.15 & 0.17 & 25.32 & 0.52 & 5.17 & $20.41 \%$ & 5.69 & Indicated \\
\hline $\begin{array}{l}\text { Imagining } \\
\text { punching } \\
\text { For } 10 \\
\text { seconds }\end{array}$ & Punch & 21.45 & 0.63 & 25.16 & 0.14 & 3.71 & $14.74 \%$ & 5.21 & Indicated \\
\hline $\begin{array}{l}\text { Tilt and } \\
\text { bend the } \\
\text { arms for } \\
20 \\
\text { seconds }\end{array}$ & No & 21.44 & 0.25 & 24.69 & 0.85 & 3.25 & $13.16 \%$ & 5.47 & Indicated \\
\hline $\begin{array}{l}\text { Tilt sloping } \\
\text { stand for } 20\end{array}$ & No & 18.18 & 0.31 & 22.16 & 0.33 & 3.98 & $17.96 \%$ & 5.96 & Indicated \\
\hline
\end{tabular}

Assiut Journal For Sport Science Arts 
Table

statistically

(2)

shows

differences between the

mean and post

measurements of the

experimental group in the

Table (3)

tests of physical and skill variables for the benefit of telemetry. The value of $(\mathrm{t})$ was greater than the tabular value at the significance level (0.05.)

The significance of the differences and the rates of improvement between the averages of the pre and post measurements of the research sample Control in tests of physical and skill variables of boxing $N=10$

\begin{tabular}{|c|c|c|c|c|c|c|c|c|c|}
\hline \multirow[t]{2}{*}{ Tests } & \multirow[t]{2}{*}{$\begin{array}{c}\text { Measure } \\
\text { unit }\end{array}$} & \multicolumn{2}{|c|}{$\begin{array}{c}\text { Pre } \\
\text { measure }\end{array}$} & \multicolumn{2}{|c|}{$\begin{array}{c}\text { Post } \\
\text { measure }\end{array}$} & \multirow{2}{*}{$\begin{array}{c}\text { Difference } \\
\text { between } \\
\text { the two } \\
\text { averages }\end{array}$} & \multirow[t]{2}{*}{$\begin{array}{c}\text { Improvement } \\
\text { rate }\end{array}$} & \multirow[t]{2}{*}{$\begin{array}{l}\text { (Value }(\mathbf{T}) \\
\text { Calculated }\end{array}$} & \multirow[t]{2}{*}{$\begin{array}{c}\text { Level of } \\
\text { significance }\end{array}$} \\
\hline & & $\mathrm{S}$ & $\pm \mathrm{E}$ & S & $\pm \mathrm{E}$ & & & & \\
\hline $\begin{array}{l}\text { Push a } \\
\text { medical } \\
\text { ball with } \\
\text { your right } \\
\text { hand }\end{array}$ & $\mathrm{Cm}$ & 6.16 & 0.28 & 7.36 & 0.16 & 1.20 & $16.30 \%$ & 3.39 & Indicated \\
\hline $\begin{array}{l}\text { Push a } \\
\text { medical } \\
\text { ball with } \\
\text { the left } \\
\text { hand }\end{array}$ & $\mathrm{Cm}$ & 5.56 & 0.36 & 6.69 & 0.24 & 1.13 & $16.89 \%$ & 3.21 & Indicated \\
\hline $\begin{array}{l}\text { Punching } \\
\text { the left } \\
\text { straight } \\
\text { fist on a } \\
\text { punching } \\
\text { bag for } 20 \\
\text { seconds }\end{array}$ & Punch & 30.12 & 0.21 & 32.69 & 0.18 & 2.57 & $7.86 \%$ & 3.17 & Indicated \\
\hline $\begin{array}{l}\text { Punching } \\
\text { the right } \\
\text { straight fist } \\
\text { on a } \\
\text { punching } \\
\text { bag for } 20 \\
\text { seconds }\end{array}$ & Punch & 43.18 & 0.47 & 45.20 & 0.11 & 2.02 & $4.46 \%$ & 3.28 & Indicated \\
\hline $\begin{array}{l}\text { Punching } \\
\text { both hands } \\
\text { on a } \\
\text { punching } \\
\text { bag with } \\
\text { straight fists } \\
\text { for } 20 \\
\text { seconds }\end{array}$ & Punch & 41.12 & 0.63 & 43.26 & 0.36 & 2.14 & $4.94 \%$ & 3.21 & Indicated \\
\hline $\begin{array}{l}\text { Punching } \\
\text { for 10 } \\
\text { seconds } \\
\text { on the } \\
\text { wall pad }\end{array}$ & Punch & 20.20 & 0.16 & 22.19 & 0.27 & 1.99 & $8.96 \%$ & 3.29 & Indicated \\
\hline $\begin{array}{l}\text { Imagining } \\
\text { punching } \\
\text { For } 10 \\
\text { seconds }\end{array}$ & Punch & 21.61 & 0.52 & 23.64 & 0.52 & 2.03 & $8.58 \%$ & 3.21 & Indicated \\
\hline $\begin{array}{l}\text { Tilt and } \\
\text { bend the } \\
\text { arms for } 20 \\
\text { seconds }\end{array}$ & No & 21.55 & 0.31 & 23.10 & 0.71 & 1.55 & $6.70 \%$ & 3.17 & Indicated \\
\hline $\begin{array}{l}\text { Tilt sloping } \\
\text { stand for } 20 \\
\text { seconds }\end{array}$ & No & 18.19 & 0.61 & 19.95 & 0.32 & 1.76 & $8.82 \%$ & 3.21 & Indicated \\
\hline
\end{tabular}


Value $(\mathrm{T})$ at significance level $(0.05)=1.782$

Table (3) shows statistically significant differences between the mean and post measurements of the experimental group in the tests of physical and skill variables for the benefit of telemetry. The value of (t) was greater than the tabular value at the significance level (0.05)

\section{Table (4)}

The significance of the differences and the rates of improvement between the averages of the dimension measurements in the experimental and control groups in the tests of physical and skill variables for the boxing players. $N 1=n 2=10$

\begin{tabular}{l|c|c|c|c|c|c|c}
\hline \hline \multicolumn{1}{c|}{ Tests } & \multirow{2}{*}{$\begin{array}{c}\text { Measure } \\
\text { unit }\end{array}$} & \multicolumn{2}{|c|}{$\begin{array}{c}\text { Experimental } \\
\text { group }\end{array}$} & \multicolumn{2}{|c|}{$\begin{array}{c}\text { Control } \\
\text { group }\end{array}$} & $\begin{array}{c}\text { (Value (T) } \\
\text { Calculated }\end{array}$ & $\begin{array}{c}\text { Level of } \\
\text { significance }\end{array}$ \\
\cline { 3 - 7 } & $\mathbf{S}$ & $\pm \mathbf{E}$ & & & & \\
\hline \hline $\begin{array}{l}\text { Push a medical ball with } \\
\text { your right hand }\end{array}$ & $\mathrm{Cm}$ & 9.10 & 0.39 & 7.36 & 0.16 & 4.36 & Indicated \\
\hline $\begin{array}{l}\text { Push a medical ball with } \\
\text { the left hand }\end{array}$ & $\mathrm{Cm}$ & 8.65 & 0.52 & 6.69 & 0.24 & 4.52 & Indicated \\
\hline $\begin{array}{l}\text { Punching the left straight } \\
\text { fist on a punching bag } \\
\text { for 20 seconds }\end{array}$ & Punch & 36.25 & 0.21 & 32.69 & 0.18 & 4.39 & Indicated \\
\hline $\begin{array}{l}\text { Punching the right } \\
\text { straight fist on a } \\
\text { punching bag for 20 } \\
\text { seconds }\end{array}$ & Punch & 49.36 & 0.17 & 45.20 & 0.11 & 4.21 & Indicated \\
\hline $\begin{array}{l}\text { Punching both hands on } \\
\text { a punching bag with } \\
\text { straight fists for 20 } \\
\text { seconds Punch }\end{array}$ & 46.21 & 0.33 & 43.26 & 0.36 & 4.28 & Indicated \\
\hline $\begin{array}{l}\text { Punching for 10 seconds } \\
\text { on the wall pad }\end{array}$ & Punch & 25.32 & 0.52 & 22.19 & 0.27 & 4.17 & Indicated \\
\hline $\begin{array}{c}\text { Imagining punching } \\
\text { For 10 seconds }\end{array}$ & Punch & 25.16 & 0.14 & 23.64 & 0.52 & 4.36 & Indicated \\
\hline $\begin{array}{l}\text { Tilt and bend the arms } \\
\text { for 20 seconds }\end{array}$ & No & 24.69 & 0.85 & 23.10 & 0.71 & 4.21 & Indicated \\
\hline $\begin{array}{l}\text { Tilt sloping stand for 20 } \\
\text { seconds }\end{array}$ & No & 22.16 & 0.33 & 19.95 & 0.32 & 4.58 & Indicated \\
\hline \hline
\end{tabular}

Value $(\mathrm{T})$ at significance level $(0.05)=1.711$

Table (4) shows that

statistically

differences

between

measurements

experimental and control and skill variables for the benefit of the telemetry. The value of $(t)$ was greater than the tabular value at the significance level (0.05)

\section{Discussion of results} groups in the tests of physical 
Table (2) shows statistically significant differences between the mean and post measurements of the experimental group in the tests of physical and skill variables for the benefit of telemetry. The calculated value (t) is greater than the tabular value at the significance level (0.05) And applied to the boxers of the experimental group, which included exercises that contributed to the development of muscle strength of the arms and contributed directly to improve the performance of the punches in question.

This is in line with the results of Abeer Shehata (2016) (11) indicating a positive effect of collision training on improving the maximum strength and muscular strength of the upper limb and the digital level in the research sample.

The result of this study is that the exercises that work on the occurrence of the length of the muscles of the joints of the joints of the joints, which work to generate muscle contraction of the voluntary works to excite the members of the other sensory and thus increase the number of motor units in the muscles working on these joints, which is a necessity to increase muscle strength and match exercises Collision with performance form.

Abul-Ela 'Abd El-Fattah (2002) agrees that muscular strength training increases significantly in the case of increasing the motor range of the joint as it helps to use the properties of the elastic components of the muscle to achieve muscular balance of the joints $(1: 247,249)$

Strength training should meet individual needs and the most appropriate training for muscles is to repeat the type of work for a number of times required by the skill and are properly strengthened and are more resistant to injury. (32:20)

This is consistent with both Nadi Ramah (2008) that these exercises aim to produce the greatest strength in the shortest possible time so that the time of contact with the feet of the earth is shortened. (14: 53)

This is what the charity of diabetes, Muhammad Jabir Barka (2009) points out, and that the effect of gravitational forces on the body leads to the emergence of a new force 
known as the force of weight, a natural force connected to the body's connection to the surface of the earth.

Table

(3) shows

statistically significant differences between mean and post measurements of experimental group in tests of physical and skill variables for the benefit of telemetry.

The calculated value $(\mathrm{t})$ is greater than the tabular value at the significance level (0.05) applied to the control group and its contents of scientific principles and principles, which included exercises to develop the elements of fitness and various exercises similar to the performance of boxing.

Which is referred to as "Mohammed Nasr Al-Din, Khalid bin Hamdan (2013)" that the training of sports organized and masturbated leads to an increase in the efficiency of the muscular system and shows directly in the ability of the muscle to produce forces, whether dynamic or fixed or distinctive speed and also increases the Speed of muscle contraction. (13: 123 - 124)

Abu Al-Ola AbdulFattah (2002) agrees that the relationship between the basic skills of a sport and its different physical requirements (general, special) is a close relationship that must be taken into account in the preparation of the players, and that there is no separation between the physical and physical preparations,

The physical elements are developed in accordance with skill requirements, which is successful in the training process and thus the level of the players. When the player has a high physical qualities can perform all the skills well. (48: 1)

This is confirmed by the "Gold bmith" (2003) that success in any basic defensive or offensive skill requires the development of essential physical components contribute to the performance of the ideal and that each basic skill contributes to the performance by nature more than a physical component

Table

(4) shows statistically significant differences between mean distance measurements in the experimental and control groups in the tests of physical and skill variables for the benefit of the telemetry. The calculated value $(\mathrm{t})$ was greater 
than the tabular value at the significance level (0.05) The muscles and flexibility of joints to become muscles and joints ready to perform collision training efficiently without injury and collision training to improve the muscle capacity of men and alarm and this clearly shows the improvement of physical variables and the performance of the experimental group of the group of the control.

This is what Cordes (2000) pointed out. The method of collision training has become one of the most widely used methods in the development of explosive force in many sports activities, which requires the integration of the maximum strength and speed of the muscle. This method has contributed to overcoming the problems that correspond The development of explosive power in relation to the relationship between power and performance (17: 69.)

In the opinion of the researcher that the collision exercises have shortened the time of contraction of muscle fibers and improved compatibility between working muscles and muscles and the researcher has observed in the design of collisions shortening the time of contact with the feet or arms of the ground and confirms that Gabita (2001) 14 and the results of this study with what reached Nadi Hamed Ramah (2008) (11) The collision training contributes to the development of muscular strength of the arms and legs and legs and this is confirmed by this study that the training exercises improve muscle capacity and positively affect the improvement of skill performance.

\section{Conclusions}

-The impact of the use of collision training on the level of physical characteristics of the experimental group boxers. -The impact of the use of training exercises at the level of skill experienced by the boxers experimental research group.

-The impact of the use of training exercises better than physical training and skill in improving the physical and skill qualities of boxing.

\section{Recommendations}

-Use of the proposed exercises because of their positive impact in improving the physical and skill characteristics of boxing skills. 
-Conduct similar studies on the impact of collision training on other skills.

-Conducting training courses for boxing trainers on the importance of using training exercises for young people.

\section{References}

1-Abeer Jamal Shehata (2016): Effect of the impact training on muscle strength and improvement of the starting distance of the swimmer's crawling on the back of the young swimmers, published scientific research, Journal of Mathematical Sciences, Faculty of Physical Education for Girls, Helwan University.

2- Abu Ela Ahmed AbdelFattah (2002): sports training, physiological foundations, Dar Al-Fikr Al-Arabi, Cairo.

3- Abdul Aziz Ahmed Nimer, Nariman Khatib (1996): weight training, the design of force programs and planning the training season, the book center for publishing, Cairo.

4- Adel Sabri Abdel Hamid (2007): Boxing, Faculty of Physical Education Al-Azhar University, Egyptian Printing, Cairo.

5- American college of sports medicine (2001): plyometric training for children and adolescent current comment USA

6- Al-Saeed Ali Nada, Mohamed Al-Kilani Ibrahim (2006), boxing science, Arab Thought House, Alexandria.

7- Boron et al. (2002): Iso kinatic Dynamics Movements of quadriceps femurs and handspring's in female hand ball playas Elerir science publishers, B.V.S ports medicine and Health G.P.A humans Editor.

8-Cardes (2000): K. Www. Reasons tostrength train for boxing.com .

\section{9-Diabetes charity,}

Mohammed Jaber Bareqa (2009): Biometric training for young people, Al-Ma'aref Establishment, part two, Alexandria.

10- Donald ehu (2008): explosive power \&strength complex training for maximum results $\mathrm{K}$ human kinetic ,London.

11- Gabbetta.v (2009): plyometrices new studies in athletic for basic considerations new studies in athletics March USA.

12- Gambetta, $R$ (2001): Plyonetric training, Track and Field 7 . manual

13- Hossam Rafki Mahmoud: (2003) boxing, the library of 
the Egyptian Renaissance, Cairo.

\section{4- Ismail Hamed Othman} (2007): Education and training boxing, Dar Al-Sa'ada for printing, Cairo.

15- Ismail Hamed Othman, Mohamed Abdel Aziz Ghoneim (2002): Boxing (Education, Training and Management), Dar Al-Saada, Cairo.

16- Joseph, E.N.C. and charles, R.E. Brup (2002): Basic athle, Tic, bell human, London,

17- Maron \& Meglym:(2000) Dynamic strength training sports and fitness series, Brown publishers M.S.A,

18-Mohamed Abdel Aziz Ghoneim (2004): The impact of the payment of the largest number of punches in the trunk area on the results of boxing matches, "Master, Faculty of Physical Education for Boys, Helwan University.

19-Mohamed Nasr Al-Din, Khalid bin Hamdan AlMassoud (2013): physiological measurements in the field of sports, Modern Book House, Cairo.

\section{0-Nadi Hamed Ramah} (2008): "The effectiveness of the collision training on the development of muscle capacity and the level of performance of jumping inside with the individual of the two legs in the successor to the jumping horse in the light of genetic diversity of the enzyme angiotensin converter (ACE)" Journal of Science and Sports Arts, Faculty of Physical Education for Girls, Cairo .

21-Read, M.Te et al: Caparison of Hamstring Quadriceps Isokincts Strength Rations and power in tennis, Squash and track athletes, British Journal of sports medicine Vol. 24 No.3, London, 2000.

\section{2-Rifai Mustafa Hassan} (1999): "A comparative study between the method of the use of weights and the method of confrontation to develop the strength of the two legs for football players" published research, the scientific journal theories and applications Faculty of Physical Education for Boys Alexandria University.

23-Saleh Mohammed Saleh, Samy Mohamed Ashour, Tariq Saladin Sayed (2000): Collision training for the rehabilitation of knee and ankle joint injuries and their relation to some kinetic variables of handball players. "Published Scientific Research, Journal of Mathematical Science and Art, Faculty of Physical Education, Assiut University.

24- Sharkey, B. J (2000) :Physiology of fitness.3rd human kinetic booksllions. 